\title{
Holocene climate variability in the North-Western Mediterranean Sea (Gulf of Lions)
}

\author{
B. Jalali ${ }^{1,2}$, M.-A. Sicre ${ }^{2}$, M.-A. Bassetti ${ }^{3}$, and N. Kallel ${ }^{1}$ \\ ${ }^{1}$ GEOGLOB, Université de Sfax, Faculté des Sciences de Sfax, route de Soukra km 4-BP.802, 3038, Sfax, Tunisia \\ ${ }^{2}$ Sorbonne Universités (UPMC, Université Paris 06)-CNRS-IRD-MNHN, LOCEAN Laboratory, \\ 4 place Jussieu, 75005 Paris, France \\ ${ }^{3}$ CEFREM, Université de Perpignan, Avenue J.-P. Alduy, 66860 Perpignan, France \\ Correspondence to: B. Jalali (bassemjalali@yahoo.fr)
}

Received: 11 June 2015 - Published in Clim. Past Discuss.: 16 July 2015

Accepted: 15 December 2015 - Published: 19 January 2016

\begin{abstract}
Sea surface temperatures (SSTs) and land-derived input time series were generated from the Gulf of Lions inner-shelf sediments (NW Mediterranean Sea) using alkenones and high-molecular-weight odd-carbon numbered $n$-alkanes (TERR-alkanes), respectively. The SST record depicts three main phases: a warm Early Holocene $\left(\sim 18 \pm 0.4^{\circ} \mathrm{C}\right.$ ) followed by a cooling of $\sim 3^{\circ} \mathrm{C}$ between 7000 and $1000 \mathrm{BP}$, and rapid warming from $\sim 1850 \mathrm{AD}$ onwards. Several superimposed multi-decadal to centennialscale cold events of $\sim 1{ }^{\circ} \mathrm{C}$ amplitude were also identified. TERR-alkanes were quantified in the same sedimentary horizons to identify periods of high Rhone River discharge and compare them with regional flood reconstructions. Concentrations show a broad increase from the Early Holocene towards the present with a pronounced minimum around 2500 BP and large fluctuations during the Late Holocene. Comparison with Holocene flood activity reconstructions across the Alps region suggests that sediments of the inner shelf originate mainly from the Upper Rhone River catchment basin and that they are primarily delivered during positive North Atlantic Oscillation (NAO).
\end{abstract}

\section{Introduction}

Several proxy records have documented surface water variability of the Mediterranean Sea during the Holocene (Kallel et al., 1997a, b, 2004; Cacho et al., 2001; Guinta et al., 2001; Rohling et al., 2002; Emeis et al., 2003; Essalami et al., 2007; Frigola et al., 2007; Castañeda et al., 2010; Boussetta et al., 2012; Martrat et al., 2014). Most of them reveal that Mediterranean Sea surface temperatures (SSTs) have undergone a long-term cooling punctuated by several cold relapses (CRs; Cacho et al., 2001; Frigola et al., 2007). While orbital forcing likely explains this long-term tendency, solar activity and volcanism contribute to forced variability (Mayewski et al., 2004; Wanner et al., 2011) together with internal variability (i.e. Atlantic multi-decadal variability (AMV), North Atlantic Oscillation; NAO) all together embedded in the multi-decadal scale variability seen in paleorecords. Josey et al. (2011) have shown that the East Atlantic pattern (EA) and the NAO are the most important modes of atmospheric variability influencing heat loss and convection in the Mediterranean basin. For example, cold intense winds closely related to negative EA and NAO would have triggered the severe coldness and deep convection in winter 2004/05 and 2005/06 in the Gulf of Lions (Schroeder et al., 2011). Owing to this tight link with the large-scale atmospheric circulation (Josey et al., 2011) annual SSTs in the Gulf of Lions are colder than the annual mean for the whole Mediterranean basin due to surface water heat loss caused by Mistral and Tramontane winds (Fig. 1). The Tramontane originates from the northwest blowing through the Naurouze passage, while Mistral winds are northerly winds channelled by the Rhone river valley that causes convection in the Gulf of $\mathrm{Li}$ ons (Auclair et al., 2000). Indeed, dense waters form over the continental shelf upon winter cooling by strong Mistral and then spread downslope to the abyssal plain. This cascading of dense waters contributes to open-ocean deep convection but the main mechanism leading to the formation of Western 


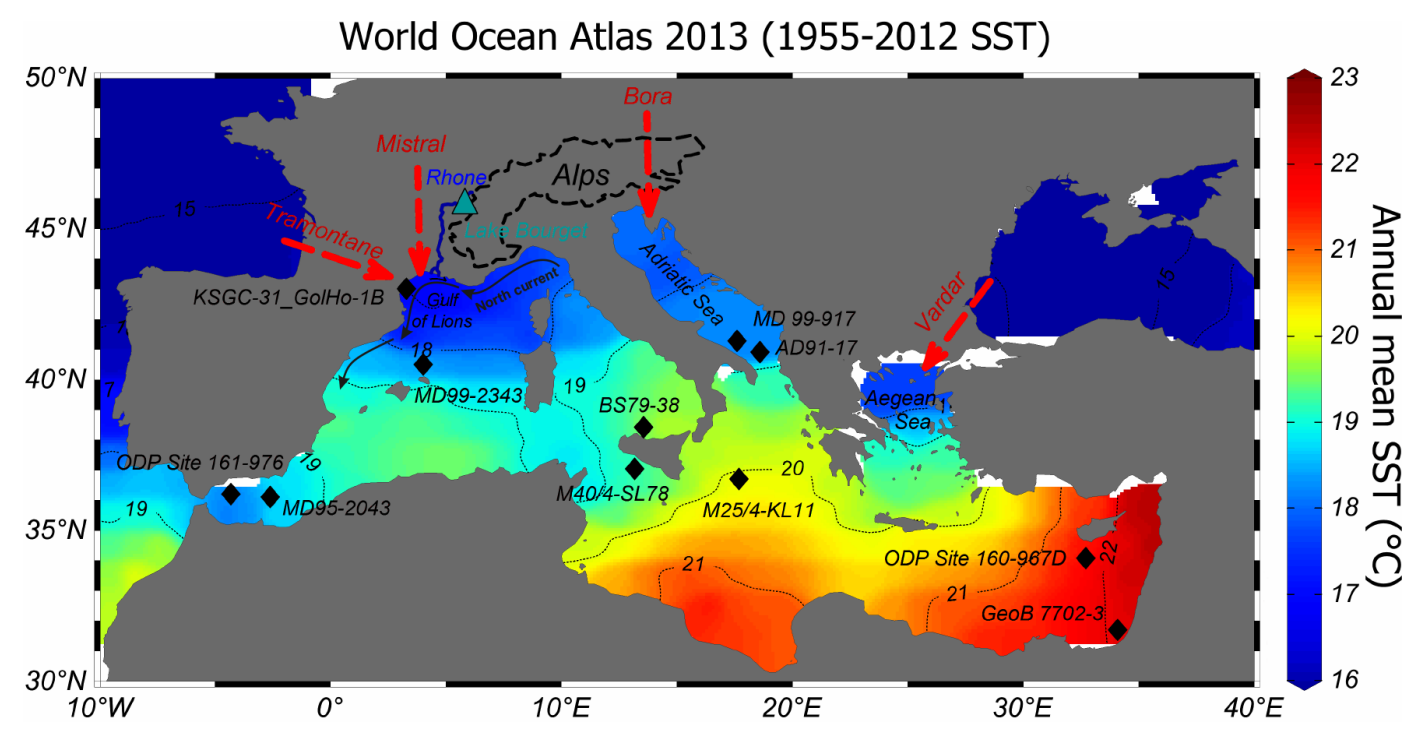

Figure 1. Map of the Mediterranean annual mean SSTs $\left({ }^{\circ} \mathrm{C} ; 1955\right.$ and 2012) from Word Ocean Atlas 2013 (http://odv.awi.de/de/data/ocean/ world_ocean_atlas_2013/) plotted using Ocean Data View (Brown, 1998). The location of the KSGC-31_GolHo-1B core and other sites discussed in the text are also reported (from West to East): ODP Site 161-976, Alboran Sea (Martrat et al., 2014); MD95-2043, Alboran Sea (Cacho et al., 2001); MD 99-2343, Balearic basin (Frigola et al., 2007); M40/4-SL78, Ionian Sea (Emeis et al., 2003); BS79-38, Southern Tyrrhenian Sea (Cacho et al., 2001); MD90-917, Southern Adriatic Sea (Essallami et al., 2007); M25/4-KL11, the Ionian Sea (Emeis et al., 2003); AD91-17, Southern Adriatic Sea (Giunta et al., 2001); ODP Site 160-967D, Levantine basin (Emeis et al., 2000); GeoB 7702-3, Levantine basin (Castañeda et al., 2010). The location of Lake Bourget in France (LDB01-1 and LDB04-1 cores) is also shown (Arnaud et al., 2012). The main winds blowing in the Mediterranean Sea are shown by red arrows.

Mediterranean Deep Water (WMDW) is open-sea convection (Béthoux et al., 2002). In that case, Mistral initiates vertical mixing till the surface mixed layer reaches the underlying saltier Levantine Intermediate Water (LIW), and upon buoyancy loss triggers deep convection (Schroeder et al., 2010). The heat and salt contents of the LIW together with wind strength are thus the main factors controlling deep convection in the Gulf of Lions (Schroeder et al., 2011).

Atmospheric circulation is also important to the hydrological budget of the Mediterranean Sea. Rainfall in the NW Mediterranean Sea mainly occurs in winter (October to March) and is very much reliant on the position of the storm tracks and strength of NAO (Hurrell et al., 2003). Indeed, during negative NAO, their southerly position results in enhanced winter rainfall over Southern Europe and the NW Mediterranean Sea, while at high NAO storm trajectories are shifted to the North and precipitations are more intense in Northern Europe. Changes in the mid-latitude atmospheric circulation in the North Atlantic are thus expected to impact on the Rhone River flow during the Holocene. Most of the precipitation occurs in autumn and contributes through different tributaries to the water discharge of the Rhone River. The upper Rhone River catchment basin receives precipitation originating from the North Atlantic during the year while from the Southern Lower Rhone tributaries are affected by extreme rainfalls in September and October due to inland penetration of maritime southerly winds. These heavy rain episodes in southern France result in intense floods causing important damages. The water and solid discharges of the Rhone River are thus highly seasonal. About $80 \%$ of the sediments of the Gulf of Lions continental shelf is supplied by the Rhone River giving rise to high sedimentation rates in this area (Aloïsi et al., 1977), especially near the river mouth. Indeed, the surface circulation in the Gulf of Lions is characterized by the geostrophic North Current flowing along the continental slope from the Ligurian to the Catalan basins (Millot, 1999). Along its path, the North Current receives suspended matter mostly from the Rhone River. In the inner shelf, the westward coastal flow advects the Rhone river plume suspended particles, settling as a wedge-shaped body and defining as mud belt (Cattaneo and Steel, 2003; Bassetti et al., 2016).

In this study, we produced a high-resolution SST record of the past 10000 years from the high accumulation rate of the Gulf of Lions shelf sediments based on alkenone paleothermometry to document past changes of surface water heat content and their link with atmospheric circulation. TERRalkanes were determined in the same sediment horizons to assess land-derived inputs from the Rhone River and identify flood periods and their relationship with the long-term and multi-decadal variability of SSTs. 
Table 1. AMS radiocarbon dated levels and their calibrated ages with a $1 \sigma$ uncertainty for the KSGC-31 gravity core. The analyses were performed at the Laboratoire de Mesure du Carbone 14, Saclay (France) and at the Beta Analytic Radiocarbon Dating Laboratory (Florida; USA). Raw radiocarbon ages were corrected and calibrated to calendar ages using the Calib7.1 software (Stuiver and Reimer, 1993) and the MARINE13 calibration data set (Reimer et al., 2013).

\begin{tabular}{|c|c|c|c|c|}
\hline Depth (cm) & Material & $\begin{array}{l}\text { Radiocarbon age } \\
\pm 1 \sigma \text { error }(\mathrm{yr} \mathrm{BP})\end{array}$ & $\begin{array}{r}\text { Calibrate age } \\
\text { (cal BP) }\end{array}$ & $\pm 1 \sigma$ error \\
\hline 5.5 & Bittium sp. & $420 \pm 30$ & $24^{\mathrm{a}}$ & 60 \\
\hline 11.5 & Tellina sp. & $430 \pm 30$ & $34^{\mathrm{a}}$ & 60 \\
\hline 18.5 & Pecten sp. & $720 \pm 40$ & $350^{\mathrm{b}}$ & 78 \\
\hline 25.5 & Venus sp. & $640 \pm 30$ & 234 & 99 \\
\hline 41 & Pecten sp. & $700 \pm 30$ & 339 & 79 \\
\hline 52 & Indet. bivalve & $960 \pm 30$ & 551 & 59 \\
\hline 71 & Arca tetragona & $1340 \pm 30$ & 851 & 80 \\
\hline 110.5 & Venus sp. & $1465 \pm 30$ & 992 & 85 \\
\hline 186.5 & Nucula sp. & $2235 \pm 40$ & 1805 & 99 \\
\hline 251 & Juvenile bivalve shells (ind.) & $2940 \pm 30$ & 2674 & 100 \\
\hline 330.5 & Venus cosina & $3870 \pm 30$ & 3796 & 106 \\
\hline 370.5 & Nuculana sp. & $4170 \pm 30$ & 4223 & 113 \\
\hline 390.5 & Turritella sp. & $4500 \pm 30$ & 4676 & 106 \\
\hline 460 & Venus sp. & $5530 \pm 45$ & 5873 & 106 \\
\hline 481 & Ostrea sp. & $5955 \pm 35$ & 6348 & 78 \\
\hline 501.5 & Turritella sp. & $6380 \pm 50$ & 6826 & 107 \\
\hline 552 & various shells & $7215 \pm 30$ & 7653 & 75 \\
\hline 583 & Turritella sp. & $7860 \pm 60$ & 8288 & 92 \\
\hline 652 & Turritella sp. & $8310 \pm 35$ & 8843 & 121 \\
\hline 700.5 & Turritella sp. & $9215 \pm 30$ & 10006 & 123 \\
\hline 701 & Turritella sp. & $9190 \pm 50$ & 9968 & 145 \\
\hline
\end{tabular}

${ }^{a}$ Post-bomb radiocarbon ages, obtained using OxCal 4.2 (Ramsey and Lee, 2013), not used for the interpolation. ${ }^{\mathrm{b}}$ Reversal date, not used for the interpolation.

\section{Material and methods}

Both a gravity core (KSGC-31) and multi-core (GolHo1B) were retrieved from virtually the same site in the Rhone mud belt deposited onto the Gulf of Lions innershelf $\left(43^{\circ} 0^{\prime} 23^{\prime \prime} \mathrm{N} ; 3^{\circ} 17^{\prime} 56^{\prime \prime} \mathrm{E}\right.$, water depth $60 \mathrm{~m}$; Fig. 1$)$. The $7.02 \mathrm{~m}$ long gravity core KSGC-31 was recovered during the GM02-Carnac cruise in 2002 on the R/V Le Suroitt, while the $20 \mathrm{~cm}$ long multi-core GolHo-1B was collected during the GolHo cruise in 2013, on the R/V Nereis. Both sediment cores were sliced continuously at a sampling step of $1 \mathrm{~cm}$ for biomarker analyses.

\subsection{Core chronology}

The age model of the gravity core KSGC-31 is based on 21 radiocarbon dates obtained by accelerator mass spectrometry (AMS) performed by the Laboratoire de Mesure du Carbone 14 (Saclay, France) and in the Beta Analytic Radiocarbon Dating Laboratory (Florida, USA; Table 1). The two uppermost dates indicate post-bomb values. The ${ }^{14} \mathrm{C}$ dates were converted into $1 \sigma$ calendar years using Calib7.1 (Stuiver and Reimer, 1993) and the MARINE 13 calibration data set with a reservoir effect of $400 \mathrm{yrs}$ (Reimer et al., 2013; Table 1). We used a local marine reservoir age of $\Delta R=23 \pm 71$ years as an additional correction (http: //calib.qub.ac.uk/marine/regioncalc.php). The age model was obtained by linear interpolation between ${ }^{14} \mathrm{C}$ dates excluding the minor reversal at $18.5 \mathrm{~cm}(350 \pm 78 \mathrm{yr})$. The age control for the upper portion of the core is based on ${ }^{210} \mathrm{~Pb}$ profile measured in the upper $10 \mathrm{~cm}$ of KSGC-31 spliced with the ${ }^{210} \mathrm{~Pb}$ profile of the GolHo-1B multi-core. Based on the ${ }^{210} \mathrm{~Pb}$ chronology, the age of the gravity KSGC-31 core-top was estimated to be approx. $1971 \pm 1.4 \mathrm{yr}$ AD. The GolHo-1B multi-core, spanning a range from $1960 \pm 5.6$ to $2013 \mathrm{yr}$ AD, thus extends the SST record to the present day. The two upper post-bomb radiocarbon ages converted using OxCal 4.2 (Ramsey and Lee, 2013) are in good agreement with the ${ }^{210} \mathrm{~Pb}$ chronology (Table 1). Details on the age model description for the past $2000 \mathrm{yr}$ as well as on splicing GolHo$1 \mathrm{~B}$ and upper part of KSGC-31 records can be found in Sicre et al. (2015). The obtained spliced KSGC-31_GolHo1B SST signal presented here covers the past 10000 years, including the 20th century. The mean sedimentation rate is $\sim 80 \mathrm{~cm}(1000 \mathrm{yr})^{-1}$. 


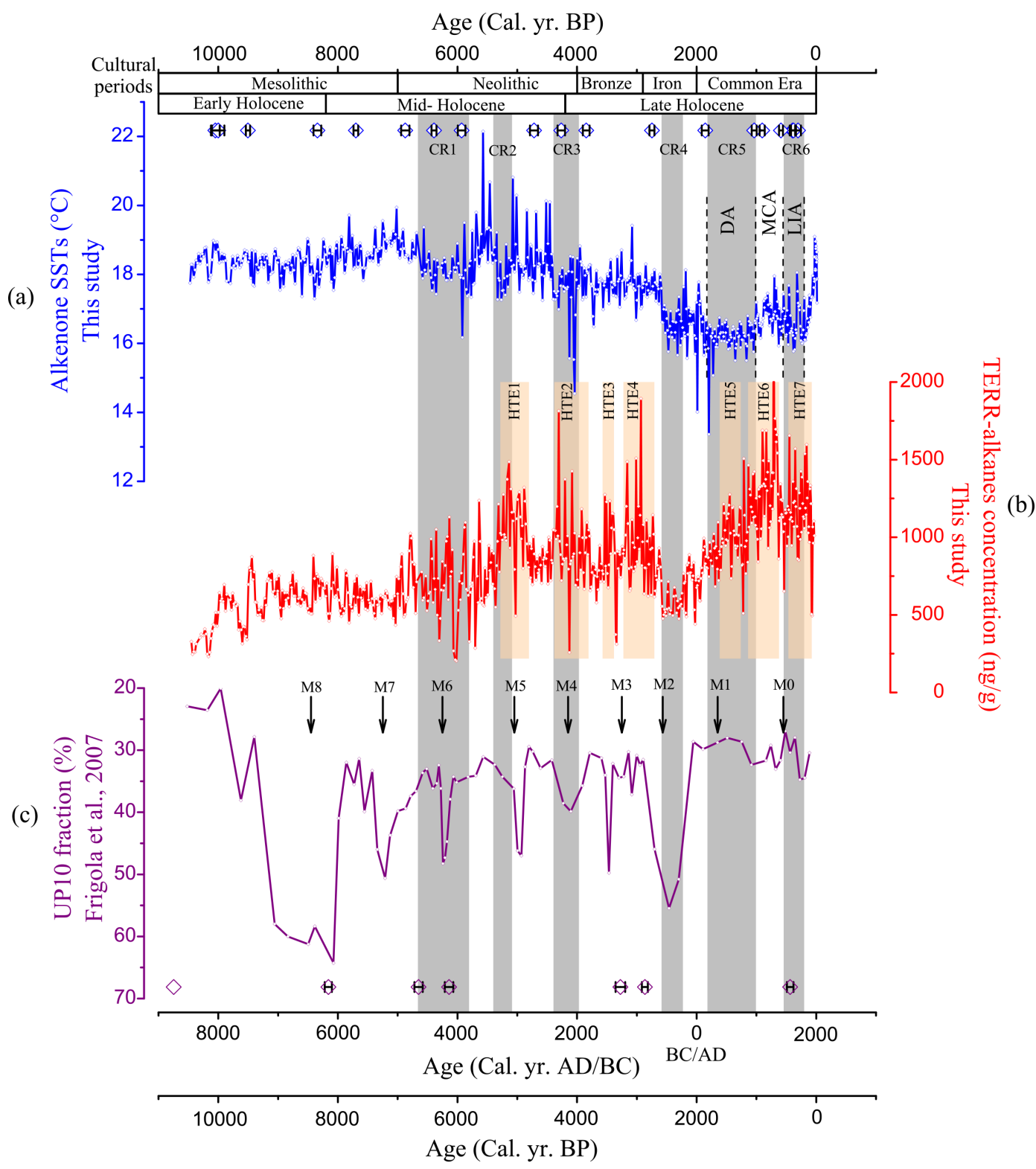

Figure 2. Alkenone SSTs and TERR-alkane concentrations at the KSGC-31_GolHo-1B core site over the past 10000 years. (a) The AMS ${ }^{14} \mathrm{C}$ radiocarbon dates for gravity core KSGC-31 are indicated by the blue diamonds; vertical dashed lines highlight the major periods of the Common Era. (b) TERR-alkane concentrations. (c) The UP10 fraction from core MD99-2343 (Frigola et al., 2007), (reversed vertical axis). Age control points for core MD99-2343 are represented by the purple diamonds. The vertical grey bars represent the six NW Mediterranean CRs no. 1-6. Vertical light brown bars indicate the periods of high flood intensity based on the high TERR-alkane episodes.

\subsection{Biomarker analyses}

Lipids were extracted from 2 to $3 \mathrm{~g}$ of freeze-dried sediments using a mixture of $(3: 1 v / v)$ dichloromethane/methanol. We performed continuous sampling of the cores at a sampling step of $1 \mathrm{~cm}$ (i.e. over 700 samples) which based on our age model translates to a mean temporal resolution of ca. 15 years. Alkenones and $n$-alkanes were isolated for the total lipid extract by silica gel chromatography and quantified by gas chromatography as described by Ternois et al. (2000).
The global calibration published by Conte et al. (2006) was used to convert the unsaturation ratio of $\mathrm{C}_{37}$ alkenones $\left(\mathrm{U}_{37}^{k^{\prime}}=\mathrm{C}_{37: 2} /\left(\mathrm{C}_{37: 2}+\mathrm{C}_{37: 3}\right)\right)$ to SSTs $\left(T\left({ }^{\circ} \mathrm{C}\right)=-0.957+\right.$ $\left.54.293\left(\mathrm{U}_{37}^{k^{\prime}}\right)-52.894\left(\mathrm{U}_{37}^{k^{\prime}}\right)^{2}+28.321\left(\mathrm{U}_{37}^{k^{\prime}}\right)^{3}\right)$ into production temperatures. External precision using this calibration has been estimated to be $\pm 1.2^{\circ} \mathrm{C}$ while analytical precision after triplicate injections is less than $0.01 \mathrm{U}_{37}^{k^{\prime}}$ unit ratio, which, in the temperature range of our data, translates into $\pm 0.3{ }^{\circ} \mathrm{C}$. 
Table 2. Timing of Holocene cold relapses (CRs). Age uncertainty was estimated using a Bayesian approach of OxCal 4.2. The cooling amplitudes were determined by the difference between temperature at the beginning of $\mathrm{CR}$ and the lowest value after applying a 60 years Fast-Fourier Transform (FFT) analysis.

\begin{tabular}{lrrrr}
\hline $\begin{array}{l}\text { Cold } \\
\text { relapses }\end{array}$ & $\begin{array}{r}\text { Central age } \\
\pm 1 \sigma \text { uncertainty }\end{array}$ & $\begin{array}{r}\text { Age interval } \\
\text { year BP }\end{array}$ & $\begin{array}{r}\text { Duration } \\
\text { year }\end{array}$ & $\begin{array}{r}\text { Amplitude } \\
{ }^{\circ} \mathrm{C}\end{array}$ \\
\hline CR1 & $6175 \pm 133$ & $6600-5750$ & 850 & $1.3 \pm 0.3$ \\
CR2 & $5195 \pm 196$ & $5350-5040$ & 310 & $1.3 \pm 0.3$ \\
CR3 & $4130 \pm 126$ & $4340-3920$ & 420 & $2.4 \pm 0.3$ \\
CR4 & $2355 \pm 142$ & $2530-2180$ & 350 & $1.4 \pm 0.3$ \\
CR5 & $1365 \pm 119$ & $1770-960$ & 810 & $2 \pm 0.3$ \\
CR6 & $320 \pm 75$ & $490-150$ & 340 & $1.1 \pm 0.3$ \\
\hline
\end{tabular}

$\mathrm{N}$-alkane concentrations were calculated using $5 \alpha$ cholestane as an external standard. Only the highmolecular-weight $\mathrm{n}$-alkanes with an odd carbon number, i.e. $\mathrm{C} 27+\mathrm{C} 29+\mathrm{C} 31+\mathrm{C} 33$ homologs (hereafter TERR-alkanes), were quantified to track land-derived inputs. These compounds are primarily synthesized by higher plants and are constituents of epicuticular waxes of leaves. Their accumulation in the sediments of Gulf of Lions is primarily associated with the discharge and deposition of the Rhone River suspended particles in relation with precipitations (Ludwig et al., 2010).

\section{Results}

Figure 2a shows the temporal evolution of SSTs at the KSGC-31_GolHo-1B site over the past 10000 years, including the post-industrial period. The data indicate warm values of about $18 \pm 0.4^{\circ} \mathrm{C}$ between ca. 10000 to $7000 \mathrm{yr} \mathrm{BP}$ followed by a long-term cooling starting $\sim 7000 \mathrm{yr}$ BP culminating during the Dark Ages (DA) and a post-industrial warming with values that do not reach those of the Early Holocene (11 700-8200 yr BP, Walker et al., 2012). Several multi-decadal to multi-centennial scale CRs on average cooler by $\sim 1{ }^{\circ} \mathrm{C}$ (grey bars in Fig. 2) are superimposed on these trends (Table 2).

TERR-alkanes are used to assess terrestrial inputs from the Rhone River and their possible link to flood events and large-scale precipitation patterns (Fig. 2b). Concentrations range from 300 to $1800 \mathrm{ng} \mathrm{g}^{-1}$ with lowest values during the Early Holocene increasing from $\sim 7000 \mathrm{yr}$ BP to present, except for a pronounced drop centred at $\sim 2500 \mathrm{BP}$. They also show large multi-centennial fluctuations mostly from $6000 \mathrm{yr}$ BP with highest values during the Common Era (past 2000 years) maximizing during the Medieval Climate Anomaly (MCA; 900-1300 yr AD), and a decrease over the last century. Seven multi-centennial scale time intervals of high TERR-alkane episodes (HTE) were identified during the past 6000 years (Table 3). HTE were defined as the time span where values exceeded one half of the standard devia- tion of the Holocene mean value after applying a 60 years Fast-Fourier Transform (FFT) analysis.

In the following section we compare our SST record to earlier published time series from the Western and Eastern Mediterranean basins. We also discuss the Gulf of Lions TERR-alkane record in relation with flood reconstructions from the Northern and Southern Alps (Wirth et al., 2013) and Bourget Lake sediments located in the Upper Rhone River catchment basin (Arnaud et al., 2012) to infer additional information on atmospheric circulation regime.

\section{Discussion}

\subsection{General trends}

The temporal evolution of SSTs in the Gulf of Lions depicts three main phases (Fig. 2a). A warm Early Holocene (11 700-8200 yr BP, Walker et al., 2012) at the time of high summer insolation in the Northern Hemisphere, ending by a cold event, CR1 (6600-5750 BP). Thereafter, SSTs show a general decline till about $1000 \mathrm{BP}$ with notable cold intervals (CR2 to CR6) and a post-industrial warming. Our record shows strong similarities with the recent world-wide compilation of 73 marine records of Marcott et al. (2013) exhibiting a warm plateau between 10000 and $5000 \mathrm{yr} \mathrm{BP}$ and a $0.7^{\circ} \mathrm{C}$ cooling from 5500 to $100 \mathrm{yr} \mathrm{BP}$ in the extratropical Northern Hemisphere ( 30 to $90^{\circ} \mathrm{N}$ ). The $2.5^{\circ} \mathrm{C}$ cooling calculated from our record between 7000 and $100 \mathrm{yr}$ BP is comparable to the $2{ }^{\circ} \mathrm{C}$ decrease calculated by Marcott et al. (2013) in the high-latitude North Atlantic, outlying the influence of the Atlantic climate on the Mediterranean SSTs. Note that cooling in the Gulf of Lions is steeper $\left(\sim 3{ }^{\circ} \mathrm{C}\right)$ when calculated from 7000 to $1000 \mathrm{BP}$.

Figure 3 compares our results with Mediterranean SST published reconstructions (Table 4). Except for the MD992343 ( $\delta^{18} \mathrm{O}$ of G. bulloides) and GeoB7702-3 cores (TEX86; Castañeda et al., 2010), these reconstructions are all based on alkenone paleothermometry. Owing to their age uncertainties and low temporal resolution, only trends and centennial to millennial-scale variability of the climate signals are retained and will be discussed here. Comparison of these regional time series reveals rising and generally warmer SSTs in all records between ca. 10000 and 7000 yrs BP. Thereafter, differences are notable between the Western and Eastern Mediterranean basins. In particular, the Alboran, the Balearic Islands, and the Gulf of Lions records all show a marked cooling through the Middle to Late Holocene. This is also the case in the central Mediterranean (Adriatic, Southern Tyrrhenian and Ionian seas), while SSTs in the Levantine basin indicate no or slight warming. This W-E evolution of Holocene SSTs highlights common features of the mid-latitude North Atlantic and NW Mediterranean that are distinct from the SE Mediterranean. The long-term SST decrease in the North Atlantic and Western Mediterranean and concomitant increase in the Eastern Mediterranean Sea is in agreement with the 


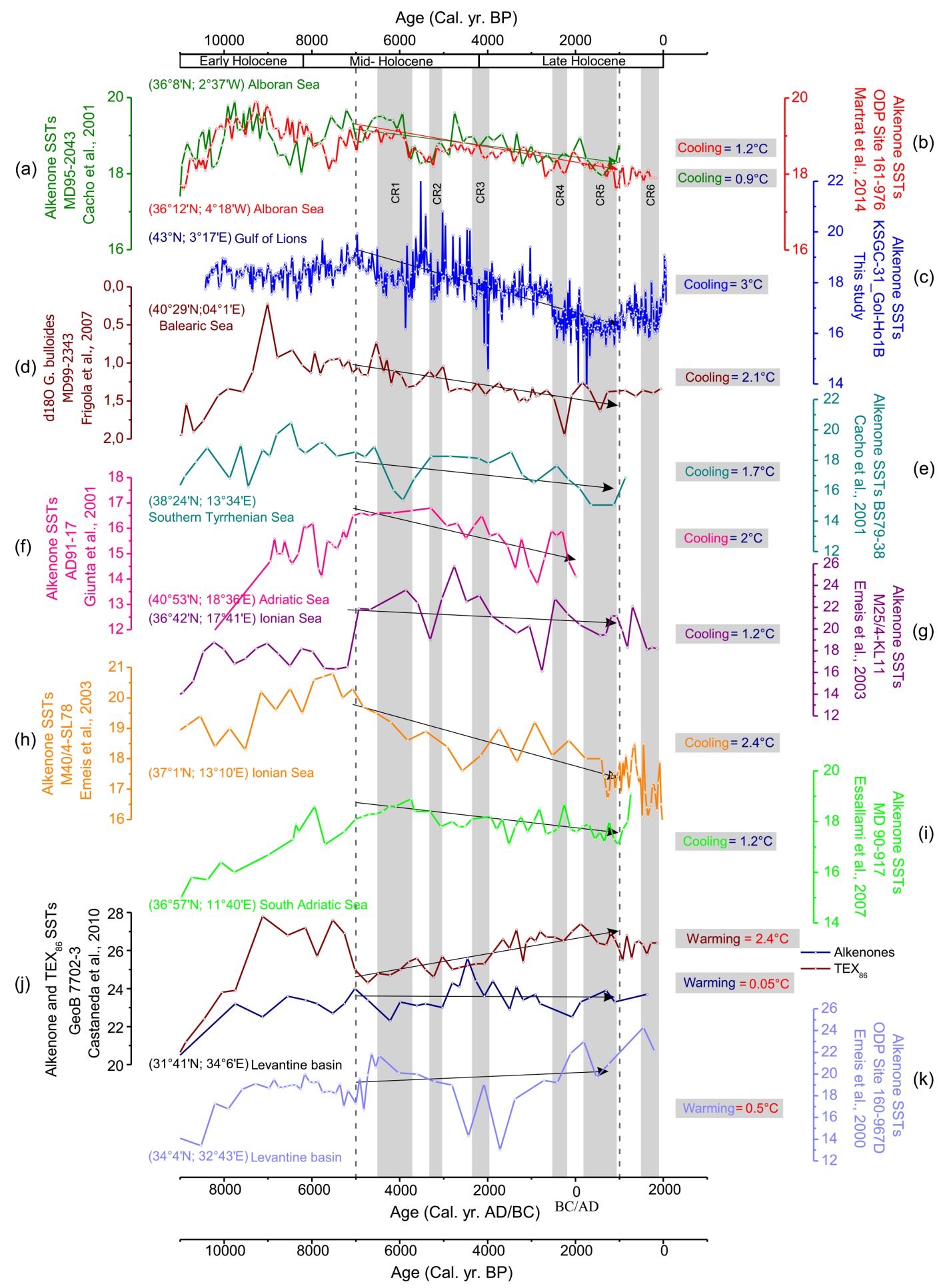

Figure 3. SST records in the Mediterranean Sea over the Holocene. (a) Core MD95-2043 from the Alboran Sea (Cacho et al., 2001). (b) ODP Site 161-976 from the Alboran Sea (Martrat et al., 2014). (c) Core KSGC-31_GolHo-1B from the Gulf of Lions (this study). (d) G. bulloides oxygen isotopic record for core MD99-2343 from the Balearic Sea (Frigola et al., 2007). (e) Core BS79-38 from the Southern Tyrrhenian Sea (Cacho et al., 2001). (f) Core AD91-17 from the Adriatic Sea (Giunta et al., 2001). (g) Core M25/4-KL11 from the Ionian Sea (Emeis et al., 2003). (h) Core M40/4-SL78 from the Ionian Sea (Emeis et al., 2003). (i) Core MD90-917 from the Southern Adriatic Sea (Essallami et al., 2007). (j) Core GeoB 7702-3 from the Levantine basin (Castañeda et al., 2010). (k) ODP Site 160-967D from the Levantine basin (Emeis et al., 2000). Vertical grey bars represent the time interval of the CRs, no. 1-6. The grey vertical dashed lines indicate the time interval used to calculate SST trends (7000 to $1000 \mathrm{yrs} \mathrm{BP})$. SST trends between 7000 and 1000 years are marked by arrows and the amplitudes $\left({ }^{\circ} \mathrm{C} / 6 \mathrm{kyr}\right.$ ) are indicated in the right of each curve. 
Table 3. Timing of high TERR-alkane episodes (HTE). Age uncertainty was estimated using a Bayesian approach of OxCal 4.2. HTE were defined as the time span where values exceed one half of the standard deviation of the Holocene mean value after applying a 60 yr Fast-Fourier Transform (FFT) analysis. Amplitudes were determined by the difference between highest TERR-alkanes and the value at the beginning of HTE.

\begin{tabular}{lrrrr}
\hline $\begin{array}{l}\text { High TERR- } \\
\text { alkanes episodes }\end{array}$ & $\begin{array}{r}\text { Central age year BP } \\
\pm 1 \sigma \text { uncertainty }\end{array}$ & $\begin{array}{r}\text { Age interval } \\
\text { year BP }\end{array}$ & $\begin{array}{r}\text { Duration } \\
\text { year }\end{array}$ & $\begin{array}{r}\text { Amplitude } \\
\text { ng g }^{-1}\end{array}$ \\
\hline HTE1 & $5995 \pm 135$ & $6235-5755$ & 480 & 388 \\
HTE2 & $4045 \pm 126$ & $4330-3760$ & 570 & 440 \\
HTE3 & $3425 \pm 172$ & $3520-3330$ & 190 & 348 \\
HTE4 & $3020 \pm 181$ & $3195-2845$ & 350 & 466 \\
HTE5 & $1390 \pm 115$ & $1565-1215$ & 350 & 335 \\
HTE6 & $832 \pm 64$ & $1090-575$ & 515 & 875 \\
HTE7 & $221 \pm 100$ & $416-26$ & 390 & 400 \\
\hline
\end{tabular}

Table 4. List of data sets used in Fig. 3.

\begin{tabular}{|c|c|c|c|c|c|c|c|}
\hline Location/Core & Proxy & $\begin{array}{l}\text { Temperature Calibration/ } \\
\text { Reference }\end{array}$ & $\begin{array}{r}\text { Latitude } \\
\left({ }^{\circ}\right)\end{array}$ & $\begin{array}{r}\text { Longitude } \\
\left({ }^{\circ}\right)\end{array}$ & $\begin{array}{r}\text { Elevation } \\
(\mathrm{m})\end{array}$ & $\begin{array}{r}\text { Resolution } \\
(\mathrm{yr})\end{array}$ & Reference \\
\hline ODP Site 161-976 & UK'37 & Müller et al. (1998) & 36.20 & -4.31 & -1108 & 34 & Martrat et al. (2014) \\
\hline MD95-2043 & UK'37 & Müller et al. (1998) & 36.10 & -2.60 & -1000 & 110 & Cacho et al. (2001) \\
\hline KSGC-31_GolHo-1B & UK'37 & Conte et al. (2006) & 43.00 & 3.29 & -60 & 15 & This study \\
\hline MD99-2343 & $\delta^{18} \mathrm{O}(\mathrm{G}$. bulloides $)$ & - & 40.49 & 4.02 & -2391 & 110 & Frigola et al. (2007) \\
\hline BS79-38 & UK'37 & Müller et al. (1998) & 38.41 & 13.57 & -1489 & 59 & Cacho et al. (2001) \\
\hline AD91-17 & UK'37 & Müller et al. (1998) & 40.90 & 18.60 & -844 & 190 & Giunta et al. (2001) \\
\hline M25/4-KL11 & UK'37 & Müller et al. (1998) & 36.70 & 17.70 & -3376 & 260 & Emeis et al. (2003) \\
\hline M40/4-SL78 & UK'37 & Müller et al. (1998) & 37.03 & 13.18 & -467 & 160 & Emeis et al. (2003) \\
\hline MD 99-917 & UK'37 & Conte et al. (2006) & 41.28 & 17.61 & -1010 & 40 & Essallami et al. (2007) \\
\hline GeoB 7702-3 & TEX86 & Kim et al. (2008); Müller et al. (1998) & 31.7 & 34.1 & -562 & 210 & Castañeda et al. (2010) \\
\hline ODP Site $160-967 D$ & UK’37 & Müller et al. (1998) & 34.07 & 32.72 & -2552 & 94 & Emeis et al. (2000) \\
\hline
\end{tabular}

findings of Rimbu et al. (2003) and their hypothesis of a longterm weakening of NAO over the Holocene due to tropical warming in winter as a result of an increase in low-latitude insolation.

\subsection{North-Western Mediterranean CRs}

Six CRs of different duration and amplitude were identified in the Gulf of Lions SST record (Table 2). The occurrence of CRs has been previously described in global compilations (Mayewski et al., 2004; Wanner et al., 2011) and seems to be associated with glacier advances in Europe (Denton and Karlén, 1973). They reflect either polar cooling or tropical aridity that likely express atmospheric circulation changes (Mayewski et al., 2004). The influence of the AMV has also been suggested (Kushnir and Stein, 2010). There are, however, discrepancies on the spatio-temporal distribution and amplitude of these events (Wanner et al., 2011, 2014). Each CR does not necessarily impact everywhere with the same intensity due to local responses to climate changes. The sensitivity of proxies or particular sediment settings (e.g. coastal areas), their seasonal character, may also be another reason for not detecting CRs in all records. For example, it is interesting to note that the $8200 \mathrm{yr} \mathrm{BP}$, well expressed in Greenland ice cores (Johnsen et al., 2001) is not found in the core
KSGC-31_GolHo-1B despite the high temporal resolution of this record (Fig. 2). When present in the extratropics, these short-term coolings have been attributed to strong cold and dry winds blowing from the North possibly triggered by a slowdown of the thermohaline circulation in the North Atlantic (Mayewski et al., 2004).

According to Kushnir and Stein (2010), cold SSTs in the tropical Atlantic would cause the formation of a highpressure over the Eastern Atlantic extending towards Western Europe and the W-Mediterranean Sea similar to EA. This large-scale atmospheric pattern would impact on temperature and precipitations in the Mediterranean region as far as in the Levant region. Intensified northerly winds during the CR thus likely reinforced convection in the Gulf of Lions by surface cooling (Schroeder et al., 2008; Josey et al., 2011). The study of the Minorca drift sediment (MD992343 core, Frigola et al., 2007) suggests that grain size in this area provides a record of bottom current vigour presumably induced by deep-water convection in the Gulf of Lions. To address this issue, we compared the $\%$ of non-carbonate fraction $>10 \mu \mathrm{m}$ (UP10) of the Minorca core to our SST reconstruction. As can be seen from Fig. $2 \mathrm{a}$ and $\mathrm{c}$ most of the CRs of the Gulf of Lions seem to correspond to higher values of UP10. This is less obvious prior to $7000 \mathrm{yr} \mathrm{BP}$ and for shorter events when age model uncertainties become limiting 


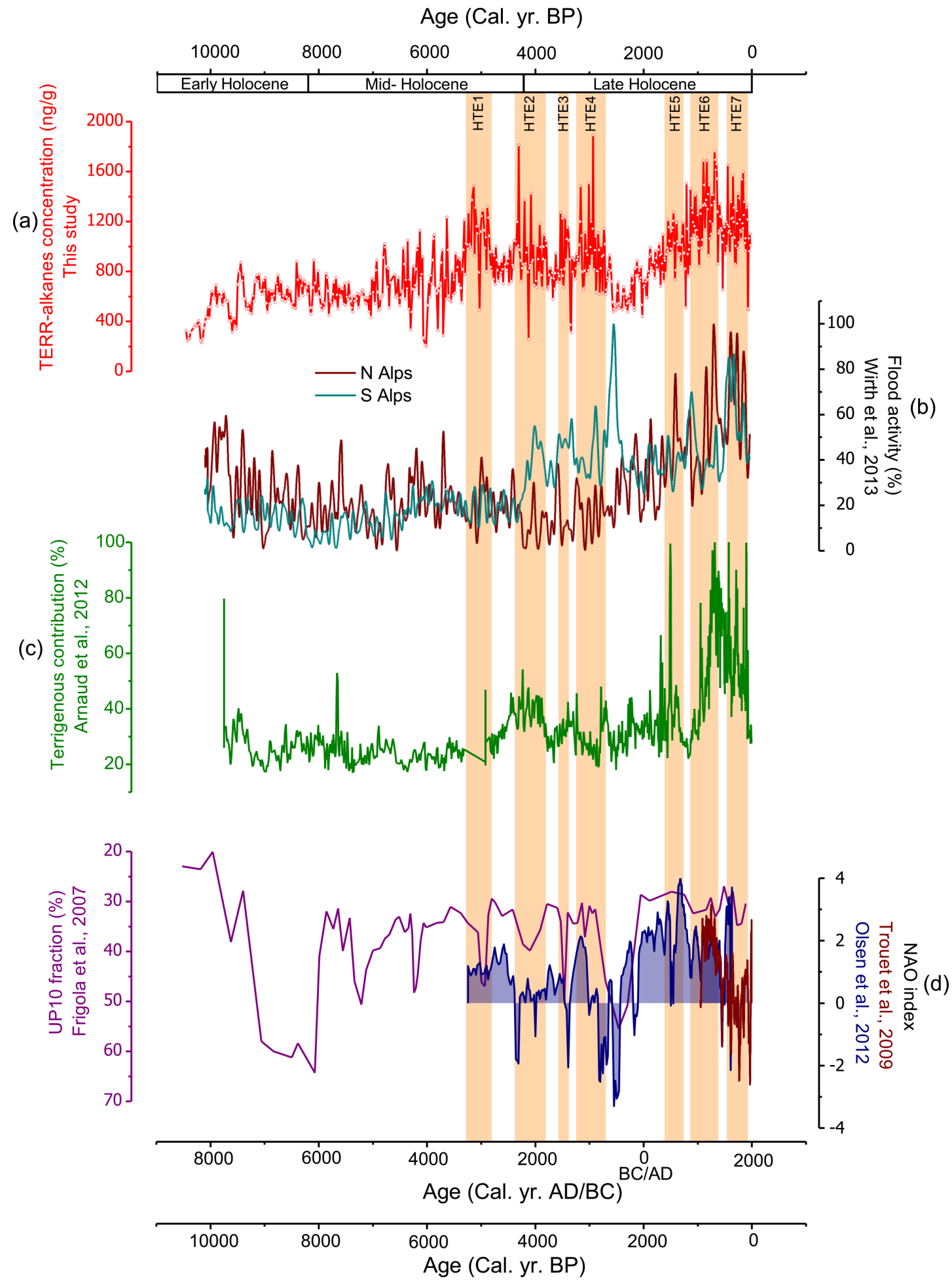

Figure 4. Holocene flood changes in the NW Mediterranean Sea and Alps region. (a) TERR-alkane abundances as a proxy of flood intensity. (b) Flood activity in the North and South Alps (from Wirth et al., 2013). (c) Total terrigenous fraction (\%) indicates the Rhone river discharge into lake Bourget (Arnaud et al., 2012) (green curve). (d) The UP10 fraction from core MD99-2343 (Frigola et al., 2007; purple curve) and the winter-NAO index from Trouet et al. (2009; in red) and Olsen et al. (2012; in blue). Vertical light brown bars indicate the periods of high flood intensity based on the high TERR-alkane episodes. 
for definite conclusions. Synchronicity between episodes of intensified upwelling in the Alboran Sea and high UP10 values at Minorca has also been discussed by Ausin et al. (2015) and explained by NAO. Based on the good match between UP10 values and the NAO index reconstruction of Olsen et al. (2012), these authors put forward the hypothesis that persistent negative NAO would have triggered both stronger upwelling in the Alboran Sea and northerly wind induced convection over the Gulf of Lions, yet alkenone SSTs in their record do not show surface water cold events. The absence of cooling in KSGC-31_GolHo-1B at the time of M8 and M7 events is also notable and suggests that Mistral was either weaker or did not affect the Gulf of Lions inner shelf area, while offshore deep convection would have taken place. However, Frigola et al. (2007) also pointed out the equivocal relationship between $\mathrm{M}$ events and geochemical tracers in the Balearic records as for example with the $\delta^{18} \mathrm{O}$ of $G$. bulloides, even though it is not a pure temperature proxy. All together, these mismatches between SSTs and M events suggest that a better understanding of the deep-water proxies and their link to SSTs is needed before any conclusion can be drawn on climatic causes for $\mathrm{M}$ events.

\subsection{Holocene flood activity}

We compared our record of TERR-alkanes to two regional reconstructions of flood intensity of the Northern and Southern Alps obtained from 15 lacustrine sediment cores (Wirth et al., 2013) and the reconstruction of the Lake Bourget paleohydrology (Arnaud et al., 2012). As can be seen from Fig. 4, the generally lower TERR-alkane values between 10000 and $7000 \mathrm{yr}$ BP broadly coincide with lower hydrological activity in Lake Bourget (Arnaud et al., 2012), between 10000 $6000 \mathrm{yr} \mathrm{BP}$ (Fig. 4c). Thereafter, as SSTs indicate colder climate conditions (CRs) TERR-alkane exhibit high fluctuations (Fig. 2). During this period broadly coincident with the Neoglaciation, advances and retreats of the Alpine glaciers would have been responsible for these centennial-scale variations (Schimmelpfennig et al., 2012). High TERR-alkanes in our record coincide with sediment flux increase in the Rhone delta plain (Provansal et al., 2003; Fanget et al., 2014), therefore indicating that TERR-alkane changes are not primarily linked to vegetation changes. Our results also indicate that TERR-alkane mainly reflect inputs from the Northern tributaries of the Rhone River except between 4200 and $2800 \mathrm{yr}$ BP time interval when high TERR-alkanes bear more resemblance with the low N-Alps flood record.

Lowest TERR-alkanes occurred during CR4, lying from 2500 and $2000 \mathrm{yr}$ BP when flood activity in S-Alps was among the highest and NAO strongly negative (Fig. 4d). This finding has been explained by the more southerly position of the North Atlantic storm tracks leading to increase cyclogenesis and precipitations in the Mediterranean Sea (Schimmelpfennig et al., 2012) as expected from negative NAO (Trigo and Davies, 2000) affecting primarily the S-Alps, as hypothesized by Wirth et al. (2013). Low TERR-alkanes consistently reflect lower precipitation in the Rhone catchment due to weak influence of Westerly winds in the N-Alps Rhone tributaries. During the Common Era flood activity and changes in Rhone River discharge both increase but as discussed by Fanget et al. (2014), human activity, i.e. erosion due to land use, likely played a role in the overall increasing delivery of land-derived material.

\section{Conclusions}

Alkenone-derived SSTs from core KSGC-31_GolHo-1B provide a regional reconstruction of Holocene climate variability of the N-W Mediterranean. After a warm plateau between 10000 and $7000 \mathrm{yr}$ BP, SSTs depict a cooling trend of $2.5^{\circ} \mathrm{C}$ from 7000 to $100 \mathrm{yr}$, comparable to the North Atlantic, primarily as a result of orbital forcing. The post-industrial warming reversed this long-term cooling trend. Six CRs of different duration and amplitude were identified, with the notable exception for the 8200 years event. Northerly and northwesterly winds blowing over the Gulf of Lions during negative NAO, and/or EA, are the most likely cause of these cold events.

TERR-alkanes accumulated in the inner shelf of the Gulf of Lions indicate low input during the Early Holocene and an increase when SSTs started to decline around ca. $6000 \mathrm{yr}$ BP. A comparison with records of flood intensity from the Alps indicates that HTE primarily originate from the Upper Rhone River catchment basin, with possible contribution of the SAlp tributaries between 4200 and $2800 \mathrm{yr}$ BP. Lowest TERRalkanes centred $\sim 2500$ years coincide with strongly negative NAO and cold SSTs when storms tracks had a most southerly position. This is when S-Alps floods were among the strongest. Our results highlight the complex and variable influence of the mid-latitude atmospheric circulation on the NW Mediterranean SSTs and precipitations on decadal to multi-decadal timescales over the Holocene.

Acknowledgements. We would like to thank MISTRALS/PALEOMEX for financial support and the crew operating the GMO2 Carnac (R/V "Le Suroît") and GolHo (R/V "Nerys") cruises. Nabil Sultan (GMO2 Carnac Chief Scientist) Serge Berné (IFREMER-CEFREM) and Bernard Dennielou (IFREMER) are thanked for giving access to the core KSGC-31 and to IFREMER laboratory facilities. The ARTEMIS programme is thanked for providing 14C from the Accelerator Mass Spectrometer located in Saclay, France (Laboratoire de Mesure du 14C). Sfax Team acknowledges support from "FP7-Marie Curie Action funded under Grant Agreement PIRSES-GA-2013-612572" and the "French-Tunisian Joint Project PHC-Utique No 14-G-1002". The authors would like to thank William Fletcher, an anonymous reviewer, and the editor Belen Martrat for their stimulating reviews that improved the manuscript.

Edited by: B. Martrat 


\section{References}

Aloïsi, J. C., Auffret, G. A., Auffret, J. P., Barusseau, J. P., Hommeril, P., Larsonneur, C., and Monaco, A.: Essai de modélisation de la sédimentation actuelle sur les plateaux continentaux français, B. Soc. Geol. Fr., 19, 183-195, 1977.

Arnaud, F., Révillon, S., Debret, M., Revel, M., Chapron, E., Jacob, J., Giguet-Covex, C., Poulenard, J., and Magny, M.: Lake Bourget regional erosion patterns reconstruction reveals Holocene NW European Alps soil evolution and paleohydrology, Quaternary Sci. Rev., 51, 81-92, doi:10.1016/j.quascirev.2012.07.025, 2012.

Auclair, F., Marsaleix, P., and Estournel, C.: Sigma coordinate pressure gradient errors: evaluation and reduction by an inverse method, J. Atmos. Ocean. Tech., 17, 1348-1367, 2000.

Ausín, B., Flores, J. A., Sierro, F. J., Cacho, I., HernándezAlmeida, I., Martrat, B., and Grimalt, J. O.: Atmospheric patterns driving Holocene productivity in the Alboran Sea (Western Mediterranean): a multiproxy approach, Holocene, 25, 1-13, doi:10.1177/0959683614565952, 2015.

Bassetti, M.-A., Berné, S., Sicre M.-A., Dennielou, B., Alonso. Y., Buscail R., Jalali, B., Hebert B., and Menniti, C.: Holocene hydrological changes of the Rhone River (NW Mediterranean) as recoded in the marine mud belt, Clim. Past, submitted, 2016.

Béthoux, J.P., Durieu de Madron, X., Nyffeler, F., and Tailliez, D.: Deep water in the western Mediterranean: peculiar 1999 and 2000 characteristics, shelf formation hypothesis, variability since 1970 and geochemical inferences, J. Mar. Syst., 33-34, 117-131, 2002.

Brown, M.: Ocean Data View 4.0, Oceanography, 11, 19-21, 1998.

Boussetta, S., Kallel, N., Bassinot, F. C., Labeyrie, L. D., Duplessy, J.-C., Caillon, N., Dewilde, F., and Rebaubier, H.: Mg/Capaleothermometry in the western Mediterranean Sea on planktonic foraminifer species Globigerina bulloides: Constraints and implications, Comptes Rendus Geoscience, 344, 267-276, 2012.

Cacho, I., Grimalt, J. O., Canals, M., Sbaffi, L., Shackleton, N., Schönfeld, J., and Zahn, R.: Variability of the western Mediterranean Sea surface temperature during the last 25000 years and its connection with the Northern Hemisphere climatic changes, Paleoceanography, 16, 40-52, 2001.

Castañeda, I. S., Schefuß, E., Pätzold, J., Sinninghe Damsté, J. S., Weldeab, S., and Schouten, S.: Millennial-scale sea surface temperature changes in the eastern Mediterranean (Nile River Delta region) over the last 27000 years, Paleoceanography, 25, PA1208, doi:10.1029/2009PA001740, 2010.

Cattaneo, A. and Steel, R. J.: Transgressive deposits: a review of their variability, Earth-Sci. Rev., 62, 187-228, 2003.

Conte, M. H., Sicre, M.-A., Rühlemann, C., Weber, J. C., Schulte, S., Schulz-Bull, D., and Blanz, T.: Global temperature calibration of the alkenone unsaturation index (UK37) in surface waters and comparison with surface sediments, Geochem. Geophys. Geosys., 7, Q02005, doi:10.1029/2005GC001054, 2006.

Denton, G. H. and Karlen, W.: Holocene climatic variations their pattern and possible cause, Quaternary Res., 3, 155-205, 1973.

Emeis, K.-C., Struck, U., Schulz, H.-M., Bernasconi, S., Sakamoto, T., and Martinez-Ruiz, F.: Temperature and salinity of Mediterranean Sea surface waters over the last 16000 years: constraints on the physical environment of S1 sapropel formation based on stable oxygen isotopes and alkenone unsaturation ratios, Palaeogeogr. Palaeocl., 158, 259-280, 2000.

Emeis, K. C., Struck, U., Blanz, T., Kohly, A., and Woß, M.: Salinity changes in the central Baltic Sea (NW Europe) over the last 10000 years, Holocene, 13, 411-421, 2003.

Essallami, L., Sicre, M.-A., Kallel, N., Labeyrie, L., and Siani, G.: Hydrological changes in the Mediterranean Sea over the last 30000 years, Geochem. Geophys. Geosys., 8, Q07002, doi:10.1029/2007GC001587, 2007.

Fanget, A. S., Berné, S., Jouet, G., Bassetti, M.-A., Dennielou, B., Maillet, G. M., and Tondut, M.: Impact of relative sea level and rapid climate changes on the architecture and lithofacies of the Holocene Rhone subaqueous delta (Western Mediterranean Sea), Sediment. Geol., 305, 35-53, doi:10.1016/j.sedgeo.2014.02.004, 2014.

Frigola, J., Moreno, A., Cacho, I., Sierro, F. J., Flores, J. A., Grimalt, J. O., Hodell, D. A., and Curtis, J. H.: Holocene climate variability in the western Mediterranean region from a deepwater sediment record, Paleoceanography, 22, PA2209, doi:10.1029/2006PA001307, 2007.

Giunta, S., Emeis, K. C., and Negri, A.: Sea-surface temperature reconstruction of the last 16000 years in the Eastern Mediterranean Sea, Rivista Italiana di Paleontologia e Stratigrafia, 107, 463-476, 2001.

Hurrell, J. W., Kushnir, Y., Ottersen, G., and Visbeck, M.: An overview of the North Atlantic Oscillation; The North Atlantic oscillation: climate significance and environmental impact, Geoph. Monog., 134, 1-35, 2003.

Johnsen, S. J., Dahl-Jensen, D., Gundestrup, N., Steffensen, J. P., Clausen, H. B., Miller, H., Masson-Delmotte, V., Sveinbjörnsdottir, A. E., and White, J.: Oxygen isotope and palaeotemperature records from six Greenland ice-core stations: Camp Century, Dye-3, GRIP, GISP2, Renland and NorthGRIP, J. Quaternary Sci., 16, 299-307, 2001.

Josey, S. A., Somot, S., and Tsimplis, M.: Impacts of atmospheric modes of variability on Mediterranean Sea surface heat exchange, J. Geophys. Res.-Oceans, 116, C02032, doi:10.1029/2010JC006685, 2011.

Kallel, N., Paterne, M., Duplessy, J.C., Vergnaud-Grazzini, C., Pujol, C., Labeyrie, L., Arnold, M., Fontugne, M., and Pierre, C.: Enhanced rainfall in the Mediterranean region during the last sapropel event, Oceanol. Ac., 20, 697-712, 1997a.

Kallel, N., Paterne, M., Labeyrie, L., Duplessy, J. C., and Arnold, M.: Temperature and salinity records of the last 18000 years, Palaeogeogr. Paleoecol., 135, 97-108, 1997b.

Kallel, N., Duplessy, J. C., Labeyrie, L., Fontugne, M., and Paterne, M.: Mediterranean Sea palaeohydrology and pluvial periods during the Late Quaternary, in: Past climate variability through Europe and Africa, Kluwer Academic, edited by: Battarbee, R. W., Gasse, F., and Stickley, C. E., Dordrecht, 6, 307-324, 2004.

Kushnir, Y. and Stein, M.: North Atlantic influence on 19th-20th century rainfall in the Dead Sea watershed, teleconnections with the Sahel, and implication for Holocene climate fluctuations, Quaternary Sci. Rev., 29, 3843-3860, 2010.

Ludwig,W., Bouwman, A. F., Dumont, E., and Lespinas, F.: Water and nutrient fluxes from major Mediterranean and Black Sea rivers: past and future trends and their implications for the basin scale budgets, Global Biogeochem. Cy., 24, GB0A13, doi:10.1029/2009GB003594, 2010. 
Marcott, S. A., Shakun, J. D., Clark, P. U., and Mix, A. C.: A reconstruction of regional and global temperature for the past 11300 years, Science, 339, 1198-1201, 2013.

Martrat, B., Jimenez-Amat, P., Zahn, R., and Grimalt, J.-O.: Similarities and dissimilarities between the last two deglaciations and interglaciations in the North Atlantic region, Quaternary Sci. Rev., 99, 122-134, doi:10.1016/j.quascirev.2014.06.016, 2014.

Mayewski, P. A., Rohling, E. E., Stager, J. C., Karlen, W., Maasch, K. A., Meeker, L. D., Meyerson, E. A., Gasse, F., van Kreveld, S., Holmgren, K., Lee-Thorp, J., Rosqvist, G., Rack, F., Staubwasser, M., Schneider, R. R., and Steig, E. J.: Holocene climate variability, Quaternary Res., 62, 243-255, 2004.

Millot, C.: Circulation in the Western Mediterranean Sea, J. Marine Syst., 20, 423-442, 1999.

Müller, P. J., Kirst, G., Ruthland, G., von Storch, I., and RosellMelé, A.: Calibration of the alkenone paleotemperature index UK' 37 based on core-tops from the eastern South Atlantic and the global ocean $\left(60^{\circ} \mathrm{N}-60^{\circ} \mathrm{S}\right)$, Geochim. Cosmochim. Ac., 62, 1757-1772, 1998.

Olsen, J., Anderson, N. J., and Knudsen, M. F.: Variability of the North Atlantic Oscillation over the past 5200 years, Nat. Geosci., 5, 808-812, 2012.

Provansal, M., Vella, C., Arnaud-Fassetta, G., Sabatier, F., and Maillet, G.: Role of fluvial sediment inputs in the mobility of the Rhône delta coast (France), Geomorphologie, 4, 271-282, 2003.

Ramsey, C.-B. and Lee, S.: Recent and planned developments of the program OxCal, Radiocarbon, 55, 720-730, 2013.

Reimer, P. J., Bard, E., Bayliss, A., Beck, J. W., Blackwell, P. G., Bronk Ramsey, C., Grootes, P. M., Guilderson, T. P., Haflidason, H., Hajdas, I., Hatt., C., Heaton, T. J., Homann, D. L., Hogg, A. G., Hughen, K. A., Kaiser, K. F., Kromer, B., Manning, S. W., Niu, M., Reimer, R. W., Richards, D. A., Scott, E. M., Southon, J. R., Staff, R. A., Turney, C. S. M., and van der Plicht, J.: IntCal13 and Marine13 Radiocarbon Age Calibration Curves 050000 years cal BP, Radiocarbon, 55, 1869-1887, 2013.

Rimbu, N., Lohmann, G., Kim, J.-H, Arz, H. W., and Schneider, R.: Arctic/North Atlantic oscillation signature in holocene sea surface temperature trends as obtained from alkenone data, Geophys. Res. Lett., 30, 6, doi:10.1029/2002GL016570, 2003.

Rohling, E. J., Mayewski, P. A., Abu-Zied, R. H., Casford, J. S. L., and Hayes, A.: Holocene atmosphere-ocean interactions: records from Greenland and the Aegean Sea, Clim. Dynam., 18, 587593, doi:10.1007/s00382-001-0194-8, 2002.

Schimmelpfennig, I., Schaefer, J.-M., Akçar, N., Ivy-Ochs, S., Finkel, R.-C., and Schlüchter, C.: Holocene glacier culminations in the Western Alps and their hemispheric relevance, Geology, 40, 891-894, 2012.

Schroeder, K., Borghini, M., Cerrati, G., Difesca, V., Delfanti, R., Santinelli, C., and Gasparini, G. P.: Multiparametric mixing analysis of the deep waters in the western Mediterranean Sea, Chem. Ecol., 24, 47-56, 2008.
Schroeder, K., Josey, S. A., Herrmann, M., Grignon, L., Gasparini, G. P., and Bryden, H. L.: Abrupt warming and salting of the Western Mediterranean Deep Water after 2005: atmospheric forcings and lateral advection, J. Geophys. Res., 115, C08029, doi:10.1029/2009JC005749, 2010.

Schroeder, K., Haza, A. C., Griffa, A., Özgökmen, T. M., Poulain, P., Gerin, R., Peggion, G., and Rixen, M.: Relative dispersion in the liguro-provencal basin: from sub-mesoscale to mesoscale, Deep-Sea Res. Pt. I, 58, 861-882, 2011.

Sicre, M.-A., Martrat, B., Jalali, B., Schmidt, S., Bassetti, M.-A., and Kallel, N.: Sea surface temperature variability in the North Western Mediterranean Sea (Gulf of Lions) during the Common Era, Earth Planet. Sc. Lett., revised, 2015.

Stuiver, M. and Reimer, P. J.: Extended 14C database and revised CALIB 3.0 14C age calibration program, Radiocarbon, 35, 215230, 1993.

Ternois, Y., Sicre M.-A., and Paterne M.: Climatic changes along the northwestern African continental margin over the last 30 kyrs, Geophys. Res. Lett., 27, 133-136, 2000.

Trigo, I.-F. and Davies, T.-D.: Decline in Mediterranean rainfall caused by weakening of Mediterranean cyclones, Geophys. Res. Lett., 27, 2913-2916, 2000.

Trouet, V., Esper, J., Graham, N. E., Baker, A., Scourse, J. D., and Frank, D. C.: Persistent positive North Atlantic oscillation mode dominated the medieval climate anomaly, Science, 324, 78-80, 2009.

Walker, M. J. C., Berkelhammer, M., Björck, S., Cwynar, L. C., Fisher, D. A., Long, A. J., Lowe, J. J., Newnham, R. M., Rasmussen, S. O., and Weiss, H.: Formal subdivision of the Holocene Series/Epoch: a Discussion Paper by a Working Group of INTIMATE (Integration of ice-core, marine and terrestrial records) and the Subcommission on Quaternary Stratigraphy (International Commission on Stratigraphy), J. Quatern. Sci., 27, 649-659, 2012.

Wanner, H., Solomina, O., Grosjean, M., Ritz, S. P., and Jetel, M.: Structure and origin of Holocene cold events, Quaternary Sci. Rev., 30, 3109-3123, 2011.

Wanner, H., Mercolli, L., Grosjean, M., and Ritz, S. P.: Holocene climate variability and change; a data-based review, J. Geol. Soc. London, 172, 254-263, doi:10.1144/jgs2013-101, 2014.

Wirth, S. B., Glur, L., Gilli, A., and Anselmetti, F. S.: Holocene flood frequency across the Central Alps - solar forcing and evidence for variations in North Atlantic atmospheric circulation, Quaternary Sci. Rev., 80, 112-128, doi:10.1016/j.quascirev.2013.09.002, 2013. 